Ater this operation. Were it resorted to more generally in ciees hopeless of recovery, on the principle of prolonging life, our efforts would very soon be directed to learn the best mode of operating, as respects the quantity of fluid to be introduced, the nature of the fluid, the times at which it might be repeated, etc., with a view to obtain the utmost prolongation of life possible: and I am sanguine enough to believe that the accuracy of observation which this would induce must lead to important results in relation to the cure of the disease. The primary object, as respects this operation, is to discover the proper remedy for the collapse, taking care that the effects of such remedy shall not be incompatible with recovery from the disease, and the restoration of the patient to health. Viewing a patient in the most extreme state of collapse from cholera, it should al ways be borne in mind that in such a patient, until life is extinct, there does not necessarily exist any disorganisation totally inconsistent with recorery. Finally, I have seen a man pulscless, speechless, cold, and livid, rise up in bed and converse, after the injection of a saline fluid into the blood, and remain for several hours capable of declaring his last wishes to those around him, or of taking his farewell of the world, of forgiving or being forgiven, or, it might be, of making his peace with his God.

3 Norfolk Crescent, August 21 st, 1854.

\section{CASE OF CHOLERA IN WHICH RECOVERY TOOK PLACE.}

By ALFRED HILL, Esq.

THE following particulars of a case of cholera may interest the readers of the Association Jourast.

CAsE. Heber Smith, aged 16 years, of sanguine temperament, living with and apprenticed to a butcher, had been generally healthy, but for the last two months had suffered from irritable bowels, though not so severcly as to incapacitate him for his employment, or to compel him to obtain medical assistance. On Saturday, June 17th, notwithstanding the irritable state of his bowels, he imprudently ate a pint of raw gooseberries, without at once experiencing any ill effects. On Sunday, June $18 \mathrm{th}$, he was called up by his master at 6 A.M.; and as he was descending the stairs he suddenly fell, from sheer inability to support himself, and quietly slipped down stairs, without contusion or any other physical injury. He immediately afterwards felt a desire to evacuate the bowels, and voided an immense quantity of matter "like water". He then returned to bed. At 12 o'clock, he was sent in a cab to the house of his father, a little in the country, having previously had a second watery evacuation. When he arrived at home, he was blue and cold. I was immediately sent for, but owing to the message not being urgent, I did not sec the patient until 3 o'clock, when the following symptoms presented themselves.

The entire surface was blue and cold, with that peculiar unyielding feeling characteristic of the dead body. He had cramps in the lower extremities; the toes were firmly flexed. There was tenderness on pressure in the right iliac fossa, but in no other part of the abdomen. The respiration was irregular; the tongue and breath were much below the normal temperature. He had a pinched expression of countenance; his eyes were deeply sunken and surrounded with very dark areola; his voice was scarcely audible, and resembled that of an infant. There was total suppression of urine; and he was in a state of constant tossing and listlessness. In addition, his mother stated that he had had a third evacuation, since his arrival at home, which she described as being "just like whey". It contained no fæcal matter, but evidently consisted of the characteristic rice-water evacuation of cholera. I had not an opportunity of seeing it, as it had been remored; but from the symptoms present, and from the statements of mother and son, both intelligent persons, no doubt re- mained as to the nature of the malady. I immediately ordered him a hot bath, and brandy mixed with an equal quantity of hot water, to be given frequently. After the bath, sinapisms were applied to the abdomen and calres of the legs, hot water bottles to the axillæ, groins, and feet, and hot flannels to every part of the body. The following pills and mixture were prescribed.

Bo Pilulæ saponis cum opio gr. $x$.

Statim sumendre.

Bo Ammonire sesquicarb. $\mathbf{j}^{\mathrm{i}}$,

Spiritús ætheris sulph.: $\mathcal{j}^{\mathrm{iij}}$

Jisture camphore zviiss. MI.

Fiat mistura cujus capiat unciam omni horâ.

R Pil. saponis cum opio gr. v.

Quartâ quâque horâ sumatur.

At half-past 9, I again visited the patient. All the symptoms were subsiding; the surface was becoming warm; the skin had resumed its natural colour; the pulse was restored; the eyes had lost their sunken appearance; the pains and cranps had disappeared; the extremities were warm; and the voice had become perfectly natural. I ordered one more pill to be given, with one dose of the mixture, and then their administration, together with that of the brandy, to be discontinued.

June 19th, 11 A.M., I again visited the patient. The bladder had resumed its function, and a considerable quantity of pale urine had been passed. Not only had the patient rallied from the state of collapse, but there was now reaction, which threatened to become fever. Perfect quiet and light farinaceous diet were enjoined; and the following antacid diaphoretic mixture was prescribed.

$$
\begin{aligned}
& \text { Bo Sodæ sesquicarbonatis jiss, } \\
& \text { Vini ipecacuanhe } \bar{j} \text { ss, } \\
& \text { Misture camphora Oss. N. }
\end{aligned}
$$

Fiat nistura cujus capiat z̧̧ $\mathbf{i}$ tâ quâque horâ.

The case has since rapidly and farourably progressed, and the patient is now convalescent.

Remarks. Among the many cases of cholera which have come under my observation, I have seen none benefited by internal remedies alone, although the materia medica has been ransacked to supply them. Some practitioners pin their faith upon venesection, some upon calomel, some upon opium, some upon astringents. It has always been my opinion, that in that stage of collapse which is so prominent a feature of Asiatic cholera, the indication is, to restore the equilibrium of the circulation, to derive from the internal organs, and particularly the bowels, which are evidently congested, and so under this congestion pour out immense quantities of serum, by which the system is prostrated and unable to rally. The most effectual method of bringing about this reaction appears to me to consist in the application of heat in every available form to the surface of the body, with which may be conjoined siuapisms to cause revulsion, the internal administration of stimuli, and opium in full (but in these cases stimulating) doses; which seems to act by allaying gastric and intestinal irritation, checking the exhausting effusion, and stimulating and supporting the powers of life. At all even'- this plan of treatment was followed in the above case by complete recovery; and, I believe, it nary be said to have effected a cure.

of the two remedies, heat externally, and opium internally, I attach most value to the former; and though I consider opium highly useful, in conjunction with heat and stimuli, I believe it would be.useless alone.

Birningham, June 30th, 1851.

[This case duly reached us, but was accidentally lost sight of : otherwise it would have appeared six weeks ago. Editor.] 